Journal of Economics and Behavioral Studies

Vol. 5, No. 7, pp. 406-419, July 2013 (ISSN: 2220-6140)

\title{
Export of Furniture Product from Malaysia: Market Prospects and Challenges
}

\author{
${ }^{1}$ Ahasanul Haque*, ${ }^{2}$ Farzana Yasmin, ${ }^{1}$ Naila Anwar, ${ }^{1}$ Zariyah Ibrahim \\ ${ }^{1}$ International Islamic University Malaysia, Malaysia \\ ${ }^{2}$ Management and Science University Malaysia, Malaysia \\ *belaliium@gmail.com
}

\begin{abstract}
This study seeks to investigate the export competitiveness of Malaysian furniture product through the application of a collection of methods, which includes Revealed Comparative Advantage (RCA), Constant Market Share (CMS) and Shift Share. SITC 821, which represents the furniture product under the Standard International Trade Classification (SITC) for the period between 2000 and 2011, has been taken into consideration. The RCA method reveals that is an escalation in the countries competitive advantage of furniture product. The results from CMS method indicate that export gain of Malaysian furniture product is to a great extent a result of the size of the market as well as its competitive effect. Furthermore, CMS analysis also illustrates there has been significant improvements in the furniture industry throughout the given period which are Period I and II, Period and II and III and Period III and I. Additionally, shift share analysis shows that countries such as Brunei, Algeria, Norway, Lebanon and Korea are the major markets with the greatest potential. However, major challenges, in terms of competition, still exist mainly with Asian countries.
\end{abstract}

Keyword: Export Competitiveness, RCA, CMS, Shift-share and Market Opportunity

\section{Introduction}

Malaysia has shown a robust growth in its economy as a result of its liberal market policies, which has paved the way for trade, entrepreneurship, industrial and greater economic development. In the World Bank report on Doing Business 2013, Malaysia ranked 12, which has improved its position by two ranks in comparison to 2012. The Malaysian manufacturing industry has played an important role in driving the economy; one noteworthy manufacturing industries is the wood-based furniture industry with has given the Malaysian economy great growth particularly in terms of the country's export revenue. It also helps provide employment opportunity for a number of skilled, semi-skilled, unskilled, educated and uneducated people, in turn stimulating economic growth (Khan and Varshney, 2012). The factors that contribute to success of the industry are, Malaysia is blessed with natural resource such as timber, human capital and advance technology (Salleh et al., 2008). Additionally, the Malaysian furniture industry is both innovation and efficient and this combination assists them in remaining competitive as well as sustaining their position within the market. Furthermore, according to the Malaysian government's Master Plan of 1996-2005 the government has noted that the furniture industry is seen as a high contributor to the economy therefore, much emphasis has been placed on it with the anticipation that this sector will highly contribute to the economic development of the nation (Adis and Sidin, 2008).

Over the past years the competitiveness of the Malaysian furniture industry has been ameliorating drastically as it has been experiencing outstanding growth, Thus, Malaysia's export performance of furniture has been going through impressive growth as furniture export rate has been escalating at a regular pace of $10 \%$ in a span of 10 years every year (Salleh et al., 2008). In the year 2008, Malaysia's export of furniture product heightened to USD 3.5 billion due to which in a short span of time Malaysia has successfully ranked the tenth exporters of furniture product globally, third in Asia and at a regional level it is placed as second tenth which provided it with the opportunity to export furniture to more than 160 countries around the world $\mathrm{Ng}$ and Thiruchelvam, 2011) which includes the conventional markets such as U.S. U.K, Japan and Australia as well as non conventional markets which such as Africa, South America, West Asia, Russia West Asia, and other ASEAN (Radam et al., 2010). In the year 2008, Malaysia's export of wooden furniture accumulated to $79.4 \%$ of the country's total furniture exports (Ng and Thiruchelvam, 2011). 
Major Issues Concern: The furniture industry has emerged as one of the most important manufacturing sectors within Penninsular Malaysia. Over the years, Malaysian furniture exports have increased at a steady rate allowing Malaysia to be one of the leading furniture exporters globally as well as regionally providing them with a competitiveness edge over their competitors. Therefore, the Malaysian furniture industry has favorably contributed to the development of Malaysian economy. More specifically, this industry is helping the economy of the country in decreasing unemployment rate as well as it is also brining in foreign currency to the country. The furniture industry will continue to grow because like any other consumer product as the population grows more and more demand for the product will exist. As the competition within the industry is intensifying, Malaysia is placed in a compromising position. In order to sustain their position within the market an understanding of the industry is essential. In view of above discussion this paper attempt to assess the export competitiveness and to identify potential export markets of furniture product of Malaysia

\section{Literature Review}

A countries competitiveness has been defined in many ways by different researchers, but the definition that is most accepted is, "The degree to which a country can, under free and fair market condition, produces goods and services which meet the test of international markets, while simultaneously maintaining and expanding the real incomes of its people in the long term" which was developed by the organization for economic cooperation and development (OESD) (Stevans et al., 2012). A country's competitiveness holds a great deal of importance in the development of national economy. In classical economics, it has been stated that a country's competitiveness can be seen through their production inputs (labour, land, capital, and natural resources) as these factors contribute directly to the economic condition of a country. However, this theory holds no value in today's globalized world as at the present time a country is required to be able to facilitate international trade key factors that contribute to this are a countries political and social environment (Tan and Gap, 2004). Competitive advantage is seen as the function of the process through which a firm organizes and manages the activities (Haque et al., 2013). By constantly innovating their product and services this can pave the way innovate in which a firm can remain competitive and sustain their position within the market. Competitive strategies consist of two components, the structure of the industry that drives the enterprise: the profitability may change hugely from one industry to another and the positioning of the company within the industry (Balkytė \& Tvaronavičienè, 2010).

Revealed Comparative Advantage (RCA): "RCA evaluates export performance as total exports of a specific product divided by the exports of that country compared to the world exports of the product, divided by total world exports" (Shafaei, 2008). With the emergence of globalization and increase in competition among industries as a result of the integration of international markets, measurement of competitiveness has become a necessity (Shafaei, 2008). Abidin and Loke (2008) asserted that RCA index of a particular country reflects a country's specialization in exporting a particular commodity in comparison to world exports for the same commodity. Under this circumstances, when a country attains a high value for the RCA index for the production of a particular commodity it indicates that the country posses comparative advantage in producing that commodity. Thus, based on theoretical underpinnings, when a country holds a superior position for producing certain commodity in comparison to other countries, it provides them with the advantage of producing commodities at a cheaper cost compared to the other countries. Serin and Civan (2008) has been mentioned by that a country enjoys comparative advantage when it exports goods that it is skillful in producing in comparison to other countries in the world. Thus, when a country is competent in producing certain commodity in a relatively lower cost than other countries then it should focus on allocating its scarce resources for the production of such commodities. Comparative advantage takes place when a country has the ability of producing a particular product at a lower cost than the trade as such country's benefit from international trade through exporting goods that they are specialized in producing through incurring lower production cost and on the other hand, importing the ones for which they have to incur a higher opportunity cost (Acharya, 2008). One of the most commonly employed approaches undertaken for measuring a country's comparative advantage is widely known as relatively comparative advantage (RCA) which has been formulated by Balassa (1965). RCA is one of the most prominent tools that allows an effective measurement of competiveness among industries (Shafaei, 2008) which has been developed in accordance to the theory of trade for measuring a country's adeptness in exporting a particular commodity in comparison to 
a group of other countries (Seyoum, 2007). RCA has emerged as a key approach for clarifying shifts that take place in trade (Cristina, 2012).

Result attained from the computation of RCA is used to examine the structural changes that take place in a country's export in a specific period of years" (Clark et al., 2005). RCA explores the relation among a country's export of a particular good in comparison to its total export and also to the total export of the commodity to a group of countries (Mirzaei, 2004). Adriana (2009) has noted that one of the main reasons for studying how a particular country performs in international trade particularly export is based on its profile of specialization which can be measured through the application of comparative advantage. Thus, RCA is an effective approach as it helps in identifying both strong as well the weak sectors in an economy and at the same time it reveals the structural movements that takes place in a country's export indicating which category of goods is the most important in the country's export (Sabonienè, 2011). Abidin and Loke (2008) examined the competitiveness of Malaysia's export performance using revealed competitive advantage. He pointed that between 2001 and 2005 Malaysia attained RCA the category of non-resources based goods such as electrical and electronics goods as well as machinery (excluding electrical). On the reverse side, the country experienced a revealed comparative disadvantage for product such as transport equipment, metal, textile and clothing and footwear. He has further noted that Malaysia's competitiveness and export strength has been shifting from non-resources based goods to resource based such as wood and wood made product. Saboniene (2009) utilized the RCA method for investigating the competiveness of Lithuania's exports over a span of seven years particularly from 2000-2007. He has demonstrated that the nation has experienced an improvement in its RCA for the export of domestic commodities. RCA has also been employed by Cristina (2012) in the context of Romania for specifically determining competitiveness in its export. He asserted as the country is opening up to international trade so is its competitiveness in terms of exports of manufacturing goods as well as other category of goods. On the other hand, Jayawickrama and Thangavelu (2010) have studied the competitiveness in export among three distinct nations. He has revealed that in comparison to Singapore other countries such as India and China are experiencing a higher competitive advantage in a wide array of manufactured goods. Besides, it has also been found that Japan and China are going through major changes as in their specialization of export as gradually they are moving into exporting newer types of product. The competitiveness of Bulgaria's export has been compared with other EU countries starting from the year 2002 to 2009 by Zhelev and Tzanov (2012). The RCA analysis has indicated that the country experiencing lower export performance rate in comparison to other EU countries.

Constant Market Share: When studying trading patterns constant market shares (CMS) analysis still remains as one of the most used technique (Ahmadi-Esfahani, 2006). This method is particularly useful to separate and quantify the contribution of the trade pattern of the country (in terms of product and geographical destinations) from the contribution of other factors (Amador and Cabral, 2007) Throughout the years constant market share approach has been criticized by several researchers for inadequacy in terms of its theoretical basis as well as empirical application (Leamer and Stern, 1970; Richardson, 1971a, b; Jepma, 1986). Despite this, it remains popular and it has frequently been used to analyze international trade. In a study by Maheran and Muhammad (2008), the constant market share approach was applied to study the level of competiveness of the Malaysia's electrical and electronics industry. In order to conduct the study a sample of exporters were selected USA, Singapore, Japan, and Hong Kong. Data from Malaysia's electrical and electronics export was divided into three Period I(1990-1994), Period II (1995-1999) and Period III (20002004) a time frame of a five years was selected to prevent year to year fluctuations. Period II (1995-1999) was placed against Period I (1990-1994), later the export of Period III (2000-2004) was placed against Period II, finally exports during Period I and III were analyzed. The outcome from CMS analysis showed that the export value changes was influenced by both the Competitive residual for period I (1990 -1994) as well as the combined structural effect of period II (1995-1999) and III (2000-2004).

Additionally, Jiménez and Martín (2010) also studied the Euro area by applying the constant market share analysis, they were able to quantify the effects of the Euro area during the time frame of 1994-2007 and later compare the out with that of the United Kingdom and the United States. According to the analysis, it showed that the expansion within the Euro area market was driver by geographical structure of its exports, because of this it was able neutralised the negative effects that was caused by their declining level of competitiveness within the market. It also indicated that generally the within the Euro area the most noticeable change is the 
competitiveness of exports and sector specialisation. Furthermore, the effects of sector specialisation seem to be less significant as well as rather uneven across the Euro area. Haque et al., (2013) applied the constant market share approach to analyze the Malaysian telecommunication product export performance, the results are general favorable. This is due to the fact that of the telecommunication industry competitiveness level as well as the size of the market. The CMS indicated that there was a growth in the industry competitiveness mostly during period III and I (2008-11and 2000-03) as opposed to period I and II (2000-03 and 2004-07) and period II and III (2004-07 and 2008-11). Tran et al. (2009) also used the constant market share approach to identify the export performance of Vietnam to EU region. Using data from 1997-2004 they were able to identify that the main reasons behind Vietnam competitive export performance is due to having relatively good international trade as well as having a good position within the market.

Shift Share Technique: In the past shift, share technique was primarily used for studying economic variables such as employment and industrial structures (Mayor et al., 2007). However, in recent time this technique is widely used for examining regional economic analysis (He, S. 2012) as well as export competitiveness and opportunities (Peh Kian-Heng, 1999; He, 2012; Wilson et al., 2005). It is a method, which measures the growth of individual markets in comparison to the members of particular group (Haque, et al., 2013). Shift share has evolved as a valuable tool in the isolation of trends in regional performance as well as for providing data to the policy makers that helps them in understanding changes in the economy (Wilson et al., 2005). As stated by Rubin (2005) the major strength of this approach is that is shows "outcomes in terms of the change in market share achieved, and this is viewed in the context of overall change in the market" (Rubin, 2005). The underlying idea behind undertaking the shirt share approach is for examining growth that exists amid regional and national average because of a region-performing superior on an average level within all industries (Haque, et al., 2013). Furthermore, the application of this approach enables to determine the how an economy is performing (Habibullah and Radam, 2009). Shift share analytical approach has received considerable attention in the assessment of export patterns. Wilson et al., (2005) shift-share technique was used to study the export performance of Singapore electronics and chemicals. Using a time frame of 19882001, they compare Singapore exports with that of a with markets such as China, Hong Kong, Korea, Malaysia, and Taiwan, which are seen as close competitors in the market.

Additionally, Srivastava (2010) implemented shift share technique in order to get an in depth insight of the impacts of the Multi-Fibre Arrangement (MFA) phaseouton textile and clothing exports of India. In order to conduct this research data from a timeframe of 1996 to 2006 was looked into. The results proved to be favorable by indicating that the industry is fortunate enough to have relatively high export opportunities. The shift share approach has also been applied by Yasin et al., (2011) in the context of tourism industry. He used this technique for exploring the performance of the Moroccan tourism. The analysis has revealed that Morocco's was able to attract less tourists and its performance lags behind other competing countries. On the other hand, Hassan et al. (2011) have used shift share in the Malaysian context, more specifically for assessing the economic performance of the countries ECER areas with the overall economy of the nation. Through the application of shift share technique, he has found that the ECER region has a disadvantage in terms of location but despite of this area has been experiencing drastic growth in their economy and are able to sustain a competitive level with the rest of the regions of the country

\section{Methodology}

For the purpose of this study, three key methodological approaches will be applied. The begin with, the first approach that will be undertaken for identifying the country's comparative advantage as well as its competitive position in terms of exports is through the application of Revealed Comparative Advantage (RCA) and Constant Market Share Analysis (CMS) method. After which shift share technique will be applied to assess the nation's potential export markets. Each if these respective methods are explained in detail below:

Revealed Comparative Advantage (RCA): Revealed Comparative Advantage (RCA) is commonly used to identify the shift in a particular country's exports in regards to its competitive advantage. The key indicators that are known for assessing the change in the competitive advantage of export are: firstly, export performance ratios and secondly, net export/total trade ratio (Balassa, 1965, Ariff and Hill, 1985). These key indicators are linked to each other and are known to emphasize the different facts of similar occurrence. 
Export Performance Ratio: Export Performance Ratio (EPR) is applied in order to gauge the RCA of a particular nation. Under the export performance ratio $\left(\mathrm{ep}_{\mathrm{ij}}\right)$ is the share of country i's export of commodity $\mathrm{j}$ in total world export of commodity $j$, as a ratio of the share of country i's total export in the world total exports. When the export performance of a country is one, it means that there exists a normal performance, in terms of export, of the commodity $\mathrm{j}$ in relation to the size of country i's of commodity $\mathrm{j}$ exporter. On the other hand, when it is two, it is an indication that commodity j's share in country i's export is two times more than the world share and so on. When the result shows a ratio that is higher than one it signals the existence of RCA. Hence, an increase in this particular ratio interprets that there has been an escalation in RCA (Balassa 1965, Haque, et al., 2013 Ariff and Hill 1985). This measure commonly includes a ratio that varies from zero to infinity however, despite this for some reasons large numbers are uncommon. When the export performance ratio is greater than unity it is then considered as a RCA, at the same time an increase in the ratio indicates an escalation of the RCA. Export performance ratio ( $\mathrm{ep}_{\mathrm{ij}}$ ) exposes the share of the country i's export of commodity j, as a ratio of the share of country i's total exports in the world total exports. It is shown as:

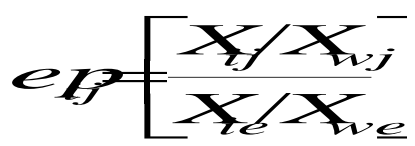

Where, $X_{\mathrm{ij}}=$ country i's export of commodity $\mathrm{j} ; \mathrm{X}_{\mathrm{wj}}=$ world exports of commodity $\mathrm{j} ; \mathrm{X}_{\mathrm{ie}}=$ country i's total exports; $X_{w e}=$ total world exports.

Net Export / Total Trade Ratio: It is possible to gain an understanding of a particular nation's changing patterns of competitive advantage or unfavorable economic activities by studying the changes that take place in terms of the percentage ratio of a country's net export in relation to total trade. Net export of commodity $j$, as a percentage of total trade in commodity $\mathrm{j}$, for country $\mathrm{i}$, is resembled by the measure $\left(\mathrm{nx}_{\mathrm{ij}}\right)$. A negative sign commonly represents a country's net exports and the formula for which is shown below:

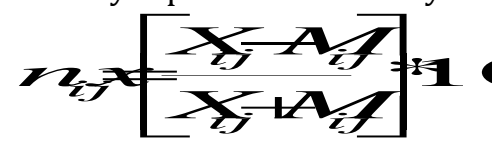

$\mathrm{X}_{\mathrm{ij}}=$ country i's exports of commodity $\mathrm{j} ; \mathrm{M}_{\mathrm{ij}}=$ country i's imports of commodity $\mathrm{j}$. The ratio for this measure ranged from +100 (which means that a particular good is being exported and not being imported) to -100 (indicating that a particular good is being imported to the country and not being exported). However, RCA is not resembled by positive or negative sign thus, even when there is a positive sign this does not mean that there is RCA and the same holds true for a negative sign. Additionally, when there is a rise in the value of the ratio it can be said that there has been a certain amount of escalation in the RCA.

Constant Market Share (CMS): A nation exports can be categorized by applying the constant market share (CMS) model there gain or loss can be categorized into four categories. The first category represents the size of market or market share, the second category is referred to as commodity composition effect, the third category is called the market distribution effect and the last category is called competitiveness effect (which is essentially captured as a residual). Export growth is usually blamed on either structural or competitive factors. In accordance to Richardson (1999), Bowen and Pelzman (1984), the method can be applied for both empirical as well as critical consistency if the weights of the initial year is utilized throughout the calculation process. Secondly, the economic interpretation of the residual terms is made explicit. Under this approach, the generalized CMS identifies an actual change in the focus country's export between two time periods. The CMS model is employed to describe a country's export growth. Here, the export performance of a particular country is compared with the 'world average'. The specific CMS model used in this study can be written as:

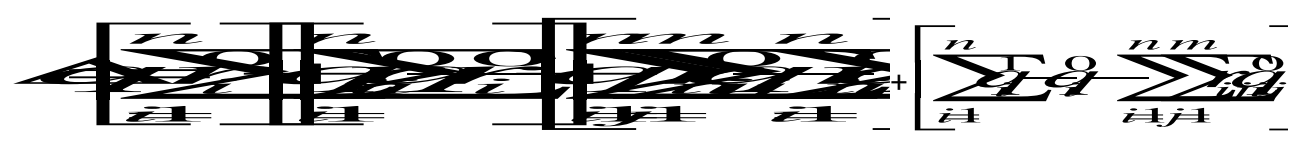

Where, $i=1,2, \ldots \ldots \ldots \ldots$, be the number of commodity; $j=1,2, \ldots \ldots \ldots, m$, be the number of markets, The superscript 1 and 0 refer to the terminal and initial time period respectively. $\mathrm{q}^{0_{i}}=$ total exports by the focus 
country of commodity $\mathrm{i}$, in the initial period; $\mathrm{q}^{1_{i}}=$ total exports by the focus country of commodity $\mathrm{i}$, in the terminal period; $\mathrm{q}^{0_{i j}}=$ export by the focus country of $\mathrm{i}^{\text {th }}$ commodity, to the $\mathrm{j}^{\text {th }}$ market in the initial period; $\mathrm{q}^{1}{ }_{\mathrm{ij}}=$ export by the focus country of $i^{\text {th }}$ commodity, to the $j^{\text {th }}$ market in the terminal period; $r=$ proportionate change in total world exports in aggregate from initial time period (0) to terminal time period (1); $r_{i}=$ proportionate change in world exports of the $\mathrm{i}^{\text {th }}$ commodity in aggregate from initial period $(0)$ to terminal period (1); $r_{i j}=$ proportionate change in the world exports of $i^{\text {th }}$ commodity to the $j^{\text {th }}$ market in aggregate from initial time period (0) to terminal time period (1); The total change, $\Delta q$, in exports of the focus country is given by

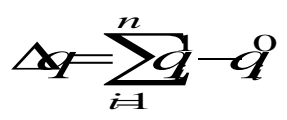

That is, Total Change in Export $=$ World trade effect $\left(1^{\text {st }}\right.$ term $)+\left(\right.$ Commodity composition effect $\left(2^{\text {nd }}\right.$ term $)+$ Market distribution effect ( $3^{\text {rd }}$ term) + Competitiveness effect $\left(4^{\text {th }}\right.$ term). These four components are briefly discussed as model specification.

World Trade Effect: The first term on the right hand side represents the world trade effect or size of market. It also illustrates a hypothetical rise in the selected country's export in the event that the country's exports are growing at similar rate to that of the world exports. It identifies that a portion of the export growth is mostly because of the general increase in world exports. Therefore $\mathrm{rq}^{0} \mathrm{i}$ is likely to be seen as the rise or fall in a country's exports due to growth in world trade assuming that initial market share remains the same. As a result, it can be assumed that a country's export volume may increase as a result of a general expansion in the total market size. In other words, a country may gain from share in world demand if it is able to maintain its market share. Following the argument of the first term, the world trade effect can be expressed as:

$$
\text { World Trade Effect }=\sum_{i=1}^{n} r q_{i}^{0}
$$

Where, $r=$ proportionate change in total world exports in aggregate from initial time period $(0)$ to terminal time period (1); $\mathrm{q}^{0} \mathrm{i}=$ total exports by the focus country of commodity $\mathrm{i}$ in the initial period; $0=$ is initial period.

Commodity Composition Effect: Secondly is the commodity composition effect. The calculation of this helps in measuring the extent to which the focus country's export composition is concentrated in commodities with high import demand. It is the weighted sum of values of export to different commodities. These weights are the deviations of the growth rates of individual commodity exports, from the growth rate of world exports in aggregate. The effect of the commodity composition largely relies on the factors endowment of a country and as well as the income and price elasticity of the product in which it is specialized in and which cause alterations in exports. The overall composition of commodity becomes negative when a country emphasizes exporting commodities with low expanded rate relative to the average rate of the world exports. Below is the illustration of the commodity composition effect:

$$
\text { Commodity Composition Effect }=\sum_{i=1}^{n}\left[r_{i} q_{i}^{0}-r q_{i}^{0}\right]
$$

Where, $r=$ proportionate change in total world exports in aggregate from initial time period $(0)$ to terminal time period (1); $r_{i}=$ proportionate change in world exports of the $i^{\text {th }}$ commodity in aggregate from initial time period (0) to terminal time period (1); $\mathrm{q}^{0_{i}}=$ total exports by the focus country's of commodity $\mathrm{i}$, in the initial period; 0 = initial period.

Market Distribution Effect: The market distribution effect is used to calculate a country's export in market as well as if the demand is growing either faster or slower in comparison to the total world export demand in those markets. The term is the weight sum of the values of each class of exports going to each market. The weight is the deviation of the growth of a particular market for a particular commodity from the average growth rate of world exports for that commodity. Generally the alteration in export is mostly due to market distribution depends on trade policies and income growth of foreign countries. There are three scenarios where there is a deviations in growth rates of exports first scenario is that the income elasticity of demand trends varies from commodity to commodity; secondly the income elasticity of demand for the same 
commodity tends to vary from one region (market) to another, and thirdly the real income may not grow at the same rate in all the regions. This in turn denotes that first and foremost, within the two respective markets there exists an unequal rate of expansion secondly, even when the constant market share in each of those markets is maintained it does not guarantee that the overall market share will remain the same. This is due to the less rapidly expanding market may not necessarily offset the change in the relative contribution of the more rapidly expanding market to overall market share. In the event when there is a positive distribution effect it is believed that the market distribution indicate that the exports of focus country's are concentrated on the relatively expanding areas in world trade. On the other hand, a negative sign reflects that the distribution effect proposes that exports are focused in a market in which demand is growing slower in comparison to the world demand. The market distribution effect is shown below:

$$
\text { Market Distribution Effect }=\sum_{i=1}^{n} \sum_{j=1}^{m} r_{i j} q_{i j}^{0}-\sum_{i=1}^{n} r_{i} q_{i}^{0}
$$

Where, $r_{i j}=$ proportionate change in world exports of commodity $\mathrm{i}$, to market $\mathrm{j}$ in aggregate from initial time period $(0)$ to terminal time period (1); $\mathrm{q}^{0_{i}}=$ total exports by the focus country of commodity $\mathrm{i}$, in the initial period; $\mathrm{q}^{0}{ }_{\mathrm{ij}}=$ total export by the focus country of commodity $\mathrm{i}$, to the $\mathrm{j}^{\text {th }}$ market in the initial period, $0=$ initial period.

Competitiveness Effect: Competitiveness effect is the last term, which is calculated in order to gauge the difference that takes place in the actual increase the focus county's actual exports, and the increase that would have taken place the nation retained its market share in those markets. Alternatively, it is the difference between the actual increase in a country's export and increase that would have happened if a country maintains its market share. In turn, this particular residual term shows the improvement or on the other hand deterioration that has taken place competitiveness of exports based on whether the term has a positive or a negative sign. When there is a negative sign it reflects that the nation has not been successful in maintaining its market share as a result of lack of competitiveness. It may be possible that the residual may provide a biased measure of general competitiveness as a result of three factors such as, interaction of the effects of commodity composition, market distribution and the residual effect. In fast growing markets, the nation might go through a decline in share in the world market if it is unable to cope with the growth to that extent. Besides, the net effect is seen in the negative sign of competitive effect as a result of favorable market as well as commodity growth. The interdependence among the three effects of market distribution, commodity composition and the residual become minor in most cases if the ratio of exports to total production become less. The formula below shows the calculation of competitiveness effect:

$$
\text { Competitiveness Effect }=\sum_{i=1}^{n}\left(q_{i}^{1}-q_{i}^{0}\right)-\sum_{i=1}^{n} \sum_{j=1}^{m} r_{i j} q_{i j}^{0}
$$

Where, $q_{i}^{1}=$ total export of the focus country of commodity $i$, in the terminal period; $q^{0} i=$ total export of the focus country of commodity $i$, in the initial period; $r_{i j}=$ proportionate change in world exports of commodity $i$, to the market $\mathrm{j} ; \mathrm{q}_{\mathrm{ij}}{ }_{\mathrm{ij}}=$ total exports of the focus country of commodity $\mathrm{i}$, to the $\mathrm{j}^{\text {th }}$ market in the initial period; 0 $=$ initial period $1=$ terminal period.

Shift- Share Method: Shift-share analysis is mostly used for studying the differences in the growth of export according to the shifts that have taken place in the market share over a span of time, whereby other methods shows the growth pattern in the form of absolute as well as percentage change in the particular variable of interest. Its attractive relies on its simplicity as well as its features, which has made it relatively popular for scanning export opportunities. More specifically, this method is mainly used for indicating the growth of markets individually in comparison with other groups selected. Furthermore, it has also been applied for exploring opportunities within exports (Green and Larson, 1991, Ahmed et al., 1992 and Ahmed and Mak, 1995, Wee and Wong, 1987). When using this technique it is necessary for measure the variable of interest at the preliminary period as well as the terminal period of the respective analysis. When studying the expected growth figure, calculations should be based on the collective growth of all markets. Additionally, the particular market's predicted growth is compared with its existing growth. When a market attains a positive net shift then market shares are gained and vice versa. The magnitude that exists in the gain or loss is an illustration of the differences that takes place in the actual performance of the specific market and the performance that it would have been able to achieve in the case where its growth rate was the same or 
equivalent to the average growth rate of the market as a whole. Computation technique is generally applied for calculation of shift share, which is shown below:

Computation Technique: The current study applies the shift share technique in order to analyze the data. Under this technique, a nation's trade in a particular time frame is analyzed based the on changes in its exports. Below the steps are outlined:

Actual Change: The calculation of the actual change for a particular market reveals the absolute value of growth. Whereby, the actual change that takes place in the growth variable in regards to a specific market, in simple terms, represents the difference in values that take place over one period to another. Let $V_{j, t}$ represents the values of the export for market $\mathrm{j}$ at the end of the terminal time period $\mathrm{t}$, and $\Delta \mathrm{V}_{\mathrm{j}}$ be the actual change in market $j$ over the specified period of time. Therefore,

$$
\Delta V_{j}=V_{j, t}-V_{j, t-1}
$$

The above equation clearly shows the existence of the following relationship. If $\Delta V_{\mathrm{j},}<0$ the $\mathrm{j}^{\text {th }}$ market experienced a decline; $=0$ the $j^{\text {th }}$ market experienced remained unchanged; $>0$ the $j^{\text {th }}$ market experienced an increase. It should be noted that $\Delta \mathrm{V}_{\mathrm{j}}>0$ implies only that market $\mathrm{j}$ increased in value. However, the growth of a particular market in relation to other markets is not illustrated by this relationship.

Total Growth Rate: The accumulated value of growth variable that is attained for all the markets $\mathrm{K}$ at the end of the initial time period is equivalent to the sum of the values for each of markets individually, that is $\Delta \mathrm{V}_{\mathrm{j}, \mathrm{t}-\mathrm{i}}$. In a similar manner, the total value of the growth variable for all the markets at the end of the terminal time period is $\Delta \mathrm{V}_{\mathrm{j}, \mathrm{t} .}$. The growth rate for all markets, $\mathrm{K}$, is equal to the ratio of the total value in the terminal time period to the corresponding value in the initial time period.

$$
K=\frac{\sum_{j=1}^{m} V_{j, t}}{\sum_{j=1}^{m} V_{j, t-1}}
$$

Where, $\mathrm{K}=$ the growth rate for all markets; $\mathrm{V}_{\mathrm{j}, \mathrm{t}}=$ the value for each market $\mathrm{j}$ for the terminal time period $\mathrm{t}$; $\mathrm{V}_{\mathrm{j}, \mathrm{t}-1}=$ the value for each market $\mathrm{j}$ for the initial time period $\mathrm{t}-1 ; \mathrm{j}=1,2, \ldots \ldots \ldots \ldots, \mathrm{m}$.

Expected Value: When a given market grows at the rate that is achieved for all the markets, the expected value of the growth valuable at the end of the terminal time period, $E\left(V_{j, t}\right)$, is the product of the actual value of this market at the end of the initial time period and the rate of change for all markets. To get this, multiply the value between the initial time period $\left(\mathrm{V}_{\mathrm{j}, \mathrm{t}-\mathrm{1})}\right)$ and growth rate for all market $(\mathrm{K})$. That is,

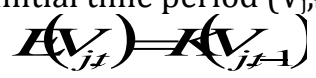

Expected Change: Expected change in the value of a growth variable for a particular market in a given time period is the difference between the expected value and actual value for the market at the end of the initial time period. Let $\mathrm{E}\left(\Delta \mathrm{V}_{\mathrm{j}}\right)$ represents the expected change. Thus,

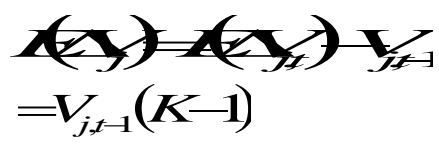

Net Shift: The net shift illustrates the difference that takes place between the actual as well as the expected change of a particular market. This difference is indicated as $\mathrm{N}_{\mathrm{j}}$. Thus,

$$
N_{j}=\Delta V_{j}-E\left(\Delta V_{j}\right)
$$

It is important to note that, when $\mathrm{N}_{\mathrm{j}}>0$ it does not mean that the $\mathrm{j}^{\text {th }}$ market's growth increases by a greater amount than it would have if it has grown at the total market rate. This conclusion holds true only when, $\mathrm{E}$ ( $\left.\Delta \mathrm{V}_{\mathrm{j}}\right)>0$. But if $\mathrm{E}\left(\Delta \mathrm{V}_{\mathrm{j}}\right)<0$ and $\mathrm{E}\left(\Delta \mathrm{V}_{\mathrm{j}}\right)<\Delta \mathrm{V}_{\mathrm{j}}<0$, then $\mathrm{N}_{\mathrm{j}}>0$. But, this entails that the $\mathrm{j}^{\mathrm{j}}$ market does not 
reduce as quickly as it would be anticipated, in turn signifying that a ratio between the actual and expected change may not be an appropriate measure.

The sum of the net shift values for all markets should be zero:

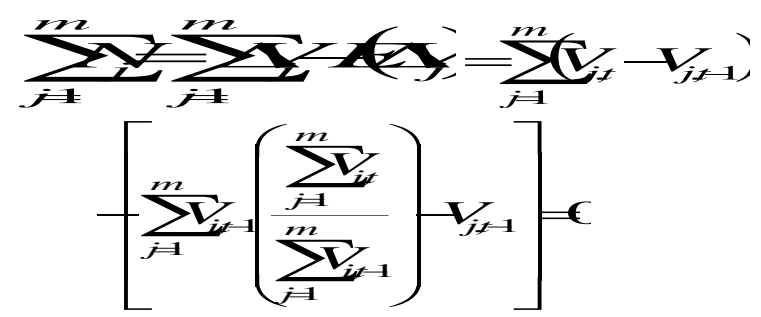

If the set of numbers $\Delta \mathrm{N}_{\mathrm{j}} \Delta, \mathrm{j}=1,2, \ldots \ldots \ldots . ., \mathrm{m}$, is separated into those numbers that are greater than or equal to zero and those that are less than zero, these subsets are identified as $\Delta \mathrm{N}_{\mathrm{j}} \Delta, \mathrm{j}=1, \ldots \ldots, \mathrm{p}$, and $\Delta \mathrm{N}_{\mathrm{j}} \Delta, \mathrm{j}=$ $1,2, \ldots . ., q$, respectively, (where $\mathrm{p}+\mathrm{q}=\mathrm{m}$ ): Therefore,

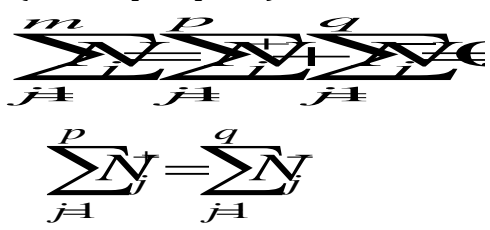

Total Absolute Net Shift: Absolute net shift is a result of the total of positive or the total of negative net shift "S". Which is,

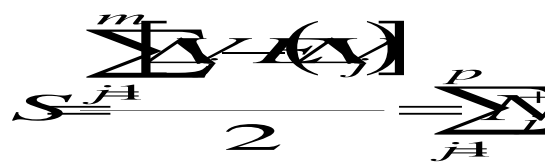

Percentage Net Shift: Percentage net shift $\left(\mathrm{P}_{\mathrm{j}}\right)$ is basically the relative gain or loss that takes place in the value of a growth variable for a specific market $j$, and in a specific time span

Thus,

$$
P_{j}=Y_{S}^{Y}(100)
$$

The percentage net shifts for all markets holds zero. Whereby, one represents total of the positive net shift, and minus one represents the total of the negative net shift.

Data Sources: The current study utilizes secondary data. The secondary data that is required for the study will be gathered from different sources such as agencies, annual reports as well as statistical booklets from various organizations. Data from the Malaysian Department of Statistics as well as the Malaysian Industrial Development Authority (MIDA), along with reports Ministry of International Trade and industry (MITI) have been employed in order to analyze the export competiveness of the nation's furniture industry. For data regarding world export, sources such as United Nation's International Trade Statistics Yearbook, New York, have been used. This study takes into account furniture product that is included in Standard International Trade Classification (SITC) represented by its three-digit code. This study has taken into consideration the export data for of Malaysian furniture industry from the time span 2000 to 2011, in other words a period of twelve years. The twelve-year period has been selected in accordance to the considerations of the three major methodological approaches described above.

In order to conduct the CMS analysis, the twelve-year period has been decomposed to three sub periods of equal span whereby each of them comprised of the four-year average for instance, 2000-2003, 2004-2007 and 2008-2011 on export values of the Malaysian furniture product that have been chosen for this study. Similarly, the RCA also took into account data from the same twelve years and at the same time; they have been categorized into three specific sub periods. The underlying motive behind dividing into three time periods is that it will assist in conducting rich comparisons between the different durations as well as it will also facilitate in exploring the strength of the applied methodology. Lastly, in the case of application of the shift-share approach, its calculation consisted of two time period taking into consideration two specific 
factors. The first consideration is that the time period that has been taken into account must be long enough for illustrating that the life cycle can be considered reasonable. However, it is also not advisable to use a time period that is very long as it holds the chance for omitting some of the important trends within the life cycle. Therefore, it is more practical and helpful when there exists a long duration between the time spans, for instance ten to fifteen years, for scanning the shifts within a particular duration. The second consideration is that the values the particular analysis can also be improved by choosing time periods for the effects of other economic forces. Taking these methodological techniques in consideration, export data for a total of twelve years have been used whereby they have been divided into two time periods. Each of the respective time periods in turn consisted of export values of an average of six years. More specifically, the first period started from the year 2000 and ended at 2005 which will be considered as being the initial period and on the other hand the second time period starts from the year 2000 and ends at 2005, which in other words is known as the terminal time period.

\section{Results and Discussion}

For studying the changes that have taken place in the Malaysian furniture industry and to gain an insight on the level of competitive advantage of furniture product two indicators of RCA have been selected from the export value of three defined periods. Below is an illustration of the results of the RCA for the furniture product with SITC code. The findings of export performance ratio of Malaysia for furniture product have been illustrated in Table 1. SITC 821 in period I, the ratio of the product show at $3.78 \%$, period II $5.67 \%$ and at period III $7.17 \%$ respectively. The export performance ratio of the furniture product shows a rising trend of RCA in the three consecutive periods (table 1).

Table 1: Export Performance Ratio and Net Export/Total Trade Ratio for Furniture Product for the three Periods (USD Million)

\begin{tabular}{lclc}
$\begin{array}{l}\text { Export Performance Ratio } \\
\text { Time Period }\end{array}$ & $\begin{array}{l}\text { Net export/Total Trade Ratio } \\
\text { Time Period }\end{array}$ \\
\hline $\begin{array}{l}\text { Period I } \\
\text { 2000-2003 }\end{array}$ & 3.78 & $\begin{array}{l}\text { Period I } \\
2000-2003\end{array}$ \\
Period II & 5.67 & 97.45 \\
2004-2007 & & $\begin{array}{l}\text { Period II } \\
2004-2007\end{array}$ \\
Period III & $7 \cdot 17$ & 99.34 \\
2008-2011 & & Period III & 99.87 \\
\hline
\end{tabular}

Net Export/Total Trade: The findings of Net Export/Total Trade of Malaysia register positive ratios for all the three periods. It is depicted in Table 2. As shown in Table 2, Period I shows $97.45 \%$ NE/TT ratio and in period II 99.35\% and in Period III 99.87\% all of them showing an increasing trend from Period I to Period III.

Table 2: Decomposition of Export Gain/Loss of Furniture Product among the three Periods (USD Million)

\begin{tabular}{llllllc}
\hline Descriptions & \multicolumn{2}{l}{$\begin{array}{l}\text { Period I and II } \\
\mathbf{2 0 0 0 - 0 3} \text { and 2004-07 }\end{array}$} & \multicolumn{2}{l}{$\begin{array}{l}\text { Period II and III } \\
\mathbf{2 0 0 4 - 0 7} \text { and 2008-11 }\end{array}$} & \multicolumn{2}{l}{$\begin{array}{l}\text { Period III and I } \\
\mathbf{2 0 0 8 - 1 1 a n d ~ 2 0 0 0 - 0 3}\end{array}$} \\
\hline Change in Export & 258.6 & 100.00 & 347.4 & 100.00 & 439.2 & 100.00 \\
World Trade Effect & 46.8 & $(16.00)$ & 51.2 & $(12.10)$ & 68.5 & $(11.34)$ \\
Commodity Composition Effect & -8.2 & $(3.70)$ & 11.3 & $(3.64)$ & 18.6 & $(3.68)$ \\
Market Distribution Effect & 31.2 & $(9.41)$ & 45.1 & $(10.31)$ & 52.2 & $(7.50)$ \\
Competitiveness Effect & 171.2 & $(64.82)$ & 261.2 & $(70.84)$ & 332.1 & $(72.68)$ \\
\hline
\end{tabular}

Note: Within bracket are indicated percentage change figure 
Constant Market Share: The constant market share (CMS) model has been used in order to examine the export performance and an indicator of the direction of competitiveness. The results of the CMS analysis depict actual gain/loss in exports are decomposed into four structural components under the three defined periods.

The World Trade Effect: The World Trade Effect of furniture product of Malaysia is presented in Table 2. All the furniture product of Malaysia show positive World Trade Effect in the comparison Periods I and II, II and III, and III and I. The product values are $16.00 \%, 12.10 \%$ and $11.34 \%$ respectively in the comparison Periods I and II, II and III, and III and I. The results of CMS analysis shows rising trend in export of the furniture product of Malaysia. Here the world trade effect contributes the positive share of the product under the three defined periods. It indicates the dominating role of the size of the market in export growth.

Commodity Composition Effect: The results of CMS analysis of furniture product are presented in Table 2, all the furniture product show a positive commodity composition effect for all three periods as in the comparison periods I and II, II and III and III and I like 3. 70\%, 3.64\% and 3.68\% respectively (Table 3).

Market Distribution Effect: Market Distribution Effect of furniture product is shown in Table 2. Malaysia attains positive Distribution Effect for product in all the three periods. All the three periods show a positive market distribution effect in the comparison periods I and II, II and III and III and I the values are 9. 41\%, $10.31 \%$ and $7.50 \%$ respectively (Table 2 ).

Competitive Effect: The competitiveness effect of furniture product is positive for the furniture product. The competitiveness is increasing for the furniture product. The percentage of three comparison periods like Period I and II, II and III and III and I show an increase the values are $64.82 \% 70.84 \%$ and 72.68 respectively. The good sign is that there is no negative value (Table 2 above).

Shift Share Analysis: Table 3 shows the percentage net shift values of the furniture product that were ranked in accordance to net shift value during the particular period for world export market. Moreover, two other methods such as absolute and percentage growth have also been included in the table, which are identified as different growth rates for the product. The results indicated that Australia attained the highest absolute growth of USD 177.82 million, followed by Belgium (USD 154.94 million) Algeria (USD 13.21 million). In the case of percentage growth Morocco shows the highest growth of 4811 followed by Norway (3960.92) and Saudi Arabia (1374.47). In the shift share list Brunei is identified as the most potential market with the net shift of 60.73 followed by Algeria (58.21) and Norway (52.40).

Table 3: Market Opportunities for Furniture Product during the period 2000-06 and 2007-11 (USD Million)

\begin{tabular}{|c|c|c|c|c|c|}
\hline \multicolumn{2}{|c|}{ Absolute Growth } & \multicolumn{2}{|c|}{ Percentage Growth } & \multicolumn{2}{|c|}{ Shift-Share } \\
\hline Country & $\begin{array}{l}\text { Growth } \\
\text { (USD) }\end{array}$ & Country & $\begin{array}{r}\text { rowth } \\
\%\end{array}$ & Net Sh & \\
\hline AUSTRALIA & 177.82 & MOROCCO & 4811.76 & BRUNEI & 60.73 \\
\hline BELGIUM & 154.94 & NORWAY & 3960.92 & ALGERIA & 58.21 \\
\hline ALGERIA & 131.21 & SAUDI ARABIA & 1374.47 & NORWAY & 52.40 \\
\hline EGYPT & 101.31 & UNITED KINGDOM & 1203.92 & LEBANON & 40.63 \\
\hline $\begin{array}{l}\text { BRUNEI } \\
\text { DARUSSALAM }\end{array}$ & 96.7 & CANADA & 1162.82 & $\begin{array}{l}\text { KOREA, REPUBLI } \\
\text { OF }\end{array}$ & C 27.09 \\
\hline VIETNAM & 93.6 & CZECH REPUBLIC & 1033.81 & JAPAN & 18.60 \\
\hline JAPAN & 90.4 & LEBANON & 838.07 & MOROCCO & 16.41 \\
\hline MOROCCO & 84.83 & NORWAY & 745.39 & VIETNAM & 11.43 \\
\hline NORWAY & 78.6 & ALGERIA & 621.99 & CZECH REPUBLIC & 8.23 \\
\hline SAUDI ARABIA & 50.61 & EGYPT & 471.66 & EGYPT & 5.45 \\
\hline
\end{tabular}

Note: Only top ten potential countries are presented 


\section{Conclusion and Implications}

In current time, Malaysian furniture industry has evolved into a highly competitive industry locally as well as internationally. Competitiveness plays an important role in the development of a nation. It is seen as the ability to be able to compete successfully with rivals (Law, 2009). Therefore, it is important to identify a particular industry's competitive advantage. Currently, Malaysian furniture products are exported all over the world. Therefore, in order to maintain their competitive status in the export of furniture product it has become increasing essential for the country to nurture the industry further. Therefore, research such as the one at hand is of great significance. The information provided from this research reveals that the country has great potential to become a market leader within the industry. The study highlights several vital implications. First and foremost, the export performance ratio reveals that the furniture product is in good position and experiencing an upward growth. Therefore, it is crucial to maintain this escalation in the export performance in order to remain competitive in the long run as it is an essential when measuring a country's export competitiveness (Momaya, 2001). Secondly, from the ratio of net export total trade furniture product demonstrate an increasing trend which is always a good sign, however, initiatives should be taken for making further improvements.

Thirdly, in the aspect of export gain/loss of Malaysia furniture product it can be seen that currently the product bear a positive percentage. Despite this, it is important to take initiative to maintain a positive trend. In the event of a negative trend, corrective action should be taken. Fourthly, the CMS results indicate that the key contributors of Malaysian furniture product are the market size as well as its competitiveness effects. Furthermore, the analysis shows steady improvements through the periods; Period I and II, Period II and III and Period I and III. Fifth, through the application of shift share analysis a clear picture of the actual and potential markets of the Malaysian furniture product can be attained. Furthermore, the shift share analysis assists in determining a country's export competitiveness (Porter, 1960). Countries such as Brunei, Algeria, Norway, Lebanon, and Korea show the greatest potential in terms of importing countries. However, there is still significant opportunity for further growth for countries such as Morocco, Saudi Arabia, United Kingdom, Canada and Czech Republic._Hence, for the further expansion of this fruitful industry it is advisable for Malaysia to increase their export to these respective countries as well as seek new potential markets. Modern day consumers are have greater knowledge and are considered to be more informed and they require a wider variety of products to choose from. Thus, companies need to provide customers with products at the right time with the right price and at a superior quality, this is how a company can remain competitive (Edmonds, 2000; Haque et al., 2013). Despite the fact that Malaysia has many advantages within the furniture industry, it is still important for them to continuously produce innovative products at a high quality to maintain its market position and image in the furniture industry. They will face many obstacles in the form of competition both regionally and internationally therefore, it is crucial to undertake studies of such nature.

\section{References}

Abidin, M. Z. \& Loke, W. H. (2008). Revealed Comparative Advantage of Malaysian Exports: The Case for Changing Export Composition. Asian Economic Papers, 7(3), 130-147.

Acharya, R. C. (2008). Analyzing International Trade Patterns: Comparative Advantage for the World's Major Economies. Journal of Comparative International Management, 11(2), 33-53

Adriana, G. (2009). The Competitiveness of the Romanian Exports during the EU Integration Process. Economic Science Series, 18(1), 310-317.

Adis, A. \& Sidin, S. (2008). Impact of Environmental Factors as Moderator on Export Marketing Performance in Wooden Furniture Industry. Jurnal Kemanusiaan, 11, 24-35.

Ahmadi-esfahani, F. Z. (2006). Constant market shares analysis: uses, limitations and prospects, 50, 510-526. Australian Journal of Agricultural \& Resource Economics, 50(4), 510-526.

Ahmed, M. I \& Mak, Y. M. (1995). Identifying Export Opportunities for Malaysia Using the Shift- Share Technique, Paper Presented at AAM Conference.

Ahmed, M. I., Gendall, P. J. \& Taufa, P. T. (1992). The Shift-Share Technique: Its Use in Identifying Export Opportunities, Paper Presented at the Australian Marketing Educator's Conference, Edith Cowan University Perth, Australia. 
Amador, J., Cabral, S. \& Maria, J. R. (2007). International trade patterns in the last four decades: How does Portugal compare with other cohesion countries? Banco de Portugal, Working Paper 14.

Ariff, M. \& Hill, H. (1985). Export - Oriented Industrialization: The Asian Experience, Sydney

Balassa, B. (1965). Trade Liberalization and Revealed Comparative Advantage. Manchester School of Economics and Social Studies, 33(2), 99-122.

Balkytė, A. \& Tvaronavičienè, M. (2010). Perception of Competitiveness in the Context of Sustainable Development: Facets Of. Sustainable Competitiveness, 11(2), 341-365.

Bowen, H. P. \& Pelzman, J. (1984). US Export Competitiveness: 1962-77. Applied Economics, 16(3), 461-473

Cristina, A. (2012). Romania's Specialization in Trade towards Eu-27-A Revealed Comparative Advantage Approach. Economic Science Series, 21(1), 54-60.

Clark, D. P., Sawyer, W. C. \& Sprinkle, R. L. (2005). Revealed comparative advantage indexes for regions of the United States. Global Economy Journal, 5(1), 1-24

Edmonds, T. (2000). Regional Competitiveness \& the Role of the Knowledge Economy, House of Commons Library. Research paper. London: Research Publications Office, 73-55.

Farhad, M., Syed, M. M. \& Saeed, Y. (2012). Export Comparative Advantage Analysis of Iranian Hen Egg by RCA \& RSCA and RC Criteria. Modern Economy, 3(5), 553-556.

Green, R. T. \& Larsen, T. L. (1991). Japanese Trade in International Perspective. International Marketing Review, 8(5), 12-26.

Habibullah, M. S. \& Radam, A. (2009). Industry Concentration in Rich and Poor States in Malaysia: Location Quotient and Shift Share Analyses. Journal of Industrial Economics, 6(1), 56-65.

Haque, A., Sultana, S. \& Momen, A. (2013). Export Performance of Malaysian Telecommunication Products: Market Prospects and Challenges, Proceedings of 3rd Asia-Pacific Business Research Conference, 2526 February, Kuala Lumpur Malaysia

Hassan, M. K. H., Rashid, Z. K. \& Hamid, K. A. (2011). East Coast Economic Region from the Perspective of Shift-Share Analysis. International Journal of Business and Society, 12(1), 79-88.

He, S. (2012). Competition among ASEAN Members in the East Asia Market an Extension to Shift-Share Analysis. Journal of Economic Studies, 39(5), 576-589.

Jayawickrama, A. \& Thangavelu, S. (2010). Trade Linkages between China, India and Singapore: Changing comparative advantage of industrial products. Journal of Economic Studies, 37(3), 248-266.

Jepma, C. J. (1986). Extensions and Application Possibilities of the Constant Market Shares Analysis. Rijkusiniversiteit, Groningen.

Jiménez, N. \& Martín, E. (2010). A Constant Market Share Analysis of the Euro Area in the Period, 1994-2007 Economic Bulletin

Khan, N. \& Varshney, P. K. (2012). Future prospects of special economic zones in India in industrial sector. International journal of marketing, financial services \& management research, 1(12), 140-151

Leamer, E. E. \& Stern, R. M. (1970). Quantitative International Economics. Allen \& Bacon, Boston.

Mayor, M., Lopez, A. \& Perez, R. (2007). Forecasting regional employment with Shift-share and ARIMA modeling. Regional Studies, 41(4), 543-551.

Mirzaei, F., Yazidani, S., Motsafavi, M. \& Gharadaghi, A. A. (2004). The Survey on Comparative Advantage of Iran's Chicken Meat Export in the Middle East. Animal Science Research Institute, The University of Tehran, Karaj, Iran, 1003-1006

Momaya, K. (2001). International Competitiveness, Hindustan Publishing, New Delhi

Ng, B. K. \& Thiruchelvam, K. (2011). Technological Innovations in Malaysia's wooden Furniture Industry: Knowledge and Linkages. African Journal of Agricultural Research, 6(16), 3654-3659

Maheran, N. \& Muhammad, N. (2008). Export Competitiveness of Malaysian Electrical and Electronic (E\&E) Product: Comparative Study of China, Indonesia and Thailand. International Journal of Business and Management, 3(7), 65-75.

Peh-Kian, H. (1999). Growth in Singapore's Exports, 1991- 96: A Shift- Share Analysis. Asian Economics J., 13 (3), 321- 344.

Radam, A., Yacob, M. R. \& Muslim, H. F. M. (2010). Technical Efficiency of the Malaysian Wooden Furniture Industry: A Stochastic Frontier Production Approach. International Business Research, 3(3), 10-15.

Richardson, J. D. (1971a). Constant Market Shares Analysis of Export Growth. Journal of International Economics, 1, 227-239. 
Richardson, D. J. \& Zhang, C. (1999). Revealing Comparative Advantage: Chaotic or Coherent Patterns across Time and Sector and U.S Trading Partner, Working Paper 7212, National Bureau of Economics Research 1050 Massachusetts Avenue, Cambridge.

Richardson, J. D. (1971b). Some Sensitivity Tests for a Constant Market Shares Analysis of Export Growth. Review of Economics and Statistics, 53, 300-304.

Rubin, R. S. (2005). Identifying Small Business Exporting Opportunities Using a Shift-Share Analysis: An Assessment and Application. Journal of Global Marketing, 19(1), 95-109.

Sabonienè, A. (2011). The Changes of Lithuanian Export Competitiveness in the Context of Economic Crisis. Economics and Management, 16, 302-308.

Saboniene, A. (2009). Lithuanian Export Competitiveness: Comparison with other Baltic States. Engineering Economics, 62(2), 49-57.

Salleh, A. L., Bakar, R. B. \& Keong, W. K. (2008). How Detrimental is Job Stress? : A Case Study of Executives in the Malaysian Furniture Industry. International Review of Business Research Papers, 4(5), 64-73

Shafaei, R., Shahriari, H. \& Moradi, M. (2009). Investigation of leather industry competitiveness in Iran. Journal of Fashion Marketing and Management, 13(3), 343-357

Shuquan, H. (2012). Competition among ASEAN members in the East Asia market: An extension to shift-share analysis. Journal of Economic Studies, 39(5), 576-589

Serin, V. \& Civan, A. (2008). Revealed Comparative Advantage and Competitiveness: A Case Study for Turkey towards the EU. Journal of Economic and Social Research, 10(2), 25-41

Seyoum, B. (2007). Revealed Comparative Advantage and Competitiveness in Services A Study with Special Emphasis on Developing Countries. Journal of Economic Studies, 34(5), 376-388.

Srivastava, D. K. (2010). Impact of MFA Phase-Out on Indian Textiles and Clothing Exports: A Shift Share Analysis Approach. South Asian Journal of Management, 17(1), 95-98.

Stevans, L. K., Neelankavil, J. P., Mendoza, R. \& Shankar, S. (2012) The Economic Competitiveness of Countries: A Principal Factors Approach. International Journal of Economics and Finance, 4(1), 76-90.

Tan, K. \& Giap, K. (2004). The IPS-NTU ASEAN $9+1$ Economic Competitiveness Ranking Indices. ASEAN Economic Bulletin, 21(2), 234-238.

Tran, T. A. D., Vo. T. T., H. M., Nguyen, A. D., Pham, T. H. \& Trinh, Q. L. (2009). The EU and Emerging Markets Schriftenreihe de Osterreichischen Gesellschaft Fur Europaforchung (ECSA Austria). European Community Studies Association of Austria Publication Series, 12, 235-262.

Wilson, P., Chern, T. S., Ping, T. S. \& Robinson, E. (2005). Assessing Singapore's export competitiveness through dynamic shift-share analysis. ASEAN Economic Bulletin, 22(2), 160-85.

Yasin, M., Alavi, J., Koubida, S. \& Small, M. H. (2011). An assessment of the competitiveness of the Moroccan tourism industry: Benchmarking implications. Benchmarking: An International Journal, 18(1), 6 - 22

Zhelev, P. \& Tzanov, L. (2012). Bulgaria's Export Competitiveness before and after EU Accession. EAST-WEST Journal of Economics and Business, 15(1\&2), 107-128. 